Explaining Increases in Higher Education Costs

Robert B. Archibald

College of William and Mary

David H. Feldman

College of William and Mary

College of William and Mary

Department of Economics

Working Paper Number 42

September 2006 
COLLEGE OF WILLIAM AND MARY

DEPARTMENT OF ECONOMICS

WORKING PAPER \# 42

September 2006

\title{
Explaining Increases in Higher Education Costs
}

\begin{abstract}
This paper presents new evidence on the conflict between two competing explanations of the increase in college costs, the cost disease theory of William Baumol and William Bowen and the revenue theory of cost of Howard Bowen. Using cross section data, the paper demonstrates that the cost disease explanation dominates.
\end{abstract}

JEL Classification: I22, I23, I28

Keywords: $\quad$ Higher education costs, cost disease, revenue theory of cost

Robert B. Archibald

Department of Economics

College of William and Mary

Williamsburg, VA 23187-8795

rbarch@wm.edu
David H. Feldman

Department of Economics

College of William and Mary

Williamsburg, VA 23187-8795

dhfeld@wm.edu 


\section{Introduction}

The real cost of higher education per full-time equivalent student has grown substantially over the last seventy-five years, and the rapid rise since the early 1980 s is a cause of considerable public concern. Opinion surveys consistently find that how much one has to pay for a college education is a serious national issue. ${ }^{1}$ Policy makers have responded to this concern. In 1997 Public Law 105-18 (Title IV, Cost of Higher Education Review, 1997) created an eleven member National Commission on the Cost of Higher Education. ${ }^{2}$ More recently, in June of 2005, Secretary of Education Margaret Spellings created a National Commission on the Future of Higher Education with a broad mandate to look into costs and accountability in higher education. When public angst is high and commissions are being created, good policy outcomes require a clear understanding of the forces behind the phenomena of concern. Unfortunately there is little consensus and considerable controversy about the causes of the rapid increase in higher education costs.

In his July 1996 Congressional testimony, David Breneman laid out the difficulty very neatly. He said that there are two competing theories explaining the rise of costs in higher education. The first relies on the insights of William Baumol and William Bowen about the cost difficulties faced by personal services industries. ${ }^{3}$ As we will explain below, the ideas behind the "cost disease" explanation in higher education have a distinguished heritage in economics. The competing explanation is Howard Bowen's

\footnotetext{
${ }^{1}$ For example, Stanley O. Ikenberry and Terry W. Hartle, 1988, report on a national survey conducted for the American Council of Education. Sixty-five percent of their respondent worried "a lot" about the costs of higher education. The Gallup Poll conducted in July 2005 found that 44.88 percent of respondents thought that cost of college were a "very serious threat" to their standard of living and 25.44 percent of respondents thought that it was a "somewhat serious" threat (see, http:/brain.gallup.com/documents/trend Question.aspx?Question=153714\&Advanced accessed 3/30/2006.)

${ }^{2}$ The Commission's report titled Straight Talk about College Costs and Prices appeared in 1998.

${ }^{3}$ See Baumol and William Bowen (1966), and Baumol (1967).
} 
(1980) "revenue theory of costs." In Bowen's view, the source of cost increases in higher education is the rising revenue stream made available to colleges and universities. Higher education institutions spend everything they can raise, so revenue is the only constraint on cost.

We have a number of goals in this paper. The first is to explain the two competing approaches in some detail. To summarize our view, cost disease rests on a firmer behavioral foundation than Bowen's revenue theory. Despite that advantage, the choice between them ultimately is empirical. This is our second task. As Breneman noted in his testimony, "it is hard to test these two theories because for most of the post WWII era, higher education has experienced remarkable revenue growth.” (p. 60). The time series evidence on college costs is indeed compatible with both the cost disease and revenue theory explanations. We propose instead a cross-section test using disaggregated price data from a broad set of industries.

One important difference between these two theories is that the cost disease is based on similarities between higher education and other industries while the revenue theory of costs is based on peculiarities of higher education as an industry. Howard Bowen is by no means alone in proposing higher education-specific explanations for cost increases. John Siegfried and Malcolm Getz (1991) list six competing explanations, one of which is cost disease and five other higher education-specific ones: cost increases arising from a change in the product mix toward more expensive disciplines, cost increases arising from shortages of higher education inputs, cost increases arising from faculty and administrators in charge having inflated desires for quality, cost increases arising from poor management in higher education, and cost increases arising from 
government regulations creating expanded duties for higher education. ${ }^{4}$ We will focus on Bowen's revenue theory of cost because, unlike the other higher education-specific causes in this list, it is overarching. It is not tied to a specific time frame. Like cost disease, the revenue theory is meant to explain the entire evolution of cost in this industry.

The difference between a higher education-specific explanation and an economywide explanation provides the basis for our test. If the revenue theory of costs or other higher education-specific explanations have great explanatory power, costs in higher education should follow an idiosyncratic time path. On the other hand, if the cost disease explanation dominates, the time path of costs in higher education should be very similar to the time paths of costs in industries that share the characteristics creating cost disease. Using cross-section industry data from 1929 to 1995 we show that the evolution of cost in higher education is very similar to the evolution of prices in other service industries that use highly educated labor and strongly dissimilar to industries producing standardized manufactured goods. We can reject the hypothesis that higher education costs follow an idiosyncratic path.

This result has important consequences for how one might go about controlling costs in higher education. If cost disease is the primary long term driver of real increases in cost per full-time equivalent student then cost control cannot be achieved without productivity growth. The problem in higher education is that productivity growth often is synonymous with lower quality. Adding more students to each class can diminish the benefit for each student, leading to diminished outcomes and lower graduation rates.

\footnotetext{
${ }^{4}$ Among others, studies by William Massy (1996) and (2003) and Ronald Ehrenberg (2000) echo many of the higher education specific explanations for cost increase discussed by Seigfried and Getz.
} 
Increasing the number of courses a professor teaches would reduce research or community service, both of which are outputs of higher education. Productivity growth that is quality neutral or quality enhancing requires a change in the technology of service delivery.

The paper follows in three additional sections. Section two provides a detailed discussion of the competing explanations for rapid cost increases in higher education. Section three contains our test. Section four discusses the policy consequences flowing from our findings.

\section{Competing Theories of College Costs}

This section gives a more detailed account of the two competing theories explaining the rapid increase in costs in higher education. We begin with a simple expository relationship between unit educational cost, educational quality, and the

\section{Figure 1. The Relationship between Quality and Unit Costs}

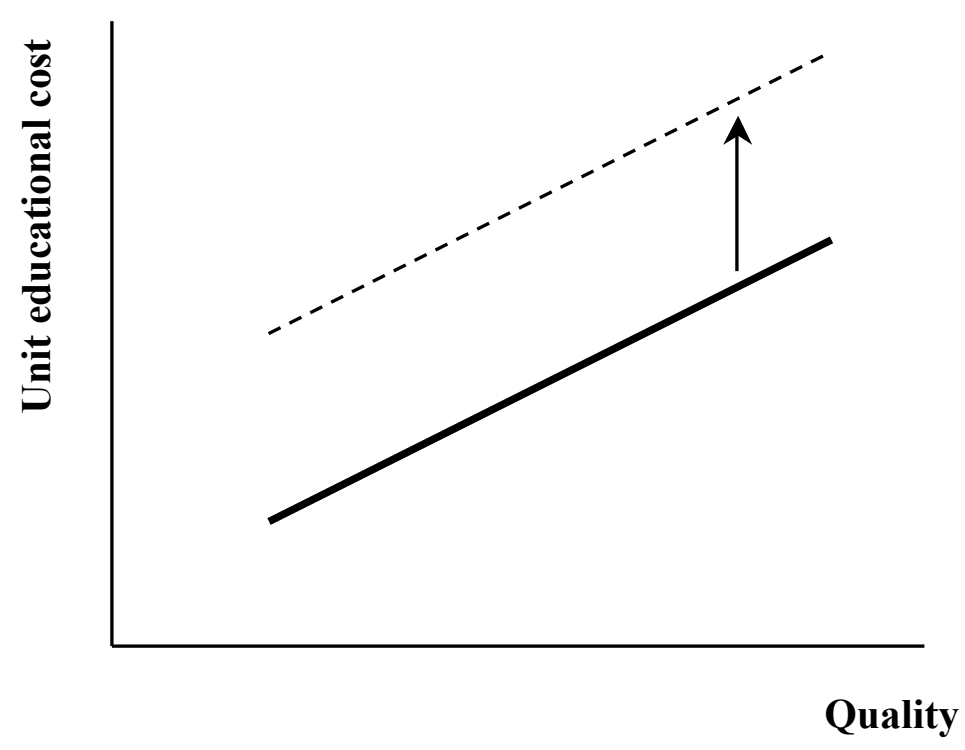


technology of service delivery. This relationship serves as a framework for discussing both cost disease and the revenue theory.

Figure 1 shows the constraint faced by a college or university. The unit educational costs-quality locus in the figure illustrates the simple idea that within the existing technology for service delivery a college or university can only achieve higher quality if it is willing and able to pay higher educational costs per unit. Two features of the figure deserve emphasis. First, it focuses on the costs of providing an education, so other costs such as housing and feeding students or fielding athletic teams are excluded. Second, the qualifier "within the existing technology" is crucial. Technology does not refer to new hardware or software alone. It refers to the entire currently understood process (or menu of ways) by which higher education services are delivered by universities. Improvements in technology that would shift the curve down are certainly possible. We focus here on the constant technology case to highlight differences in the two theories under discussion.

In brief, the revenue theory of costs says that an institution chooses a point on this constraint based on what it can afford. In other words, given its revenue the institution determines its costs. The presence of cost disease would lead this constraint to shift up over time. In this case, to maintain quality in the face of rising cost requires increased revenue. Without matching revenue increases from public appropriations, private giving, or tuition, quality must erode over time. The constraint also can be moved by productivity-increasing technological change. Cost reducing technological progress in this sector would shift the constraint downward. This would permit higher quality at a constant cost per unit, lower cost at a constant quality, or some of both. 
Cost Disease - The cost disease explanation is traditionally traced to Baumol and William G. Bowen (1966) and Baumol (1967). Yet this work is strikingly similar to parallel research done in international economics by Bela Balassa (1964) and Paul Samuelson (1964). And Balassa's and Samuelson's arguments are a formalization of insights that trace back to the work of David Ricardo in the early $19^{\text {th }}$ century.

Cost disease is based on the idea that technological progress that increases labor productivity (and thus reduces unit cost) is not randomly distributed across industries and over time. The likelihood of productivity growth is related to how labor is used in the industry.

"In some cases labor is primarily an instrument - an incidental requisite for the attainment of the final product, while in other fields of endeavor, for all practical purposes the labor is itself the end product." [Baumol (1967) p. 416]

Manufacturing is the prime example of the former, and higher education is an excellent example of the latter. ${ }^{5}$ If you can cut the amount of labor that it takes to make most manufactured goods, competition in the long run transfers the higher productivity to workers in the form of higher wages and/or lower prices. On the other hand, for many services productivity gains are either hard to achieve or would be considered decreases in quality.

Despite their lagging productivity personal service industries have to compete for workers with goods-producing industries. Because they are experiencing technological progress, the goods-producing industries will be giving substantial wage increases to their workers. The only way that service industries can compete for workers is by raising

\footnotetext{
${ }^{5}$ Baumol and Bowen's book focused on performing arts and Baumol's article was about services in general, but Baumol and Sue Anne Batey Blackman (1995) explicitly discussed the application of the cost disease theory to higher education.
} 
wages also, and this causes prices of services to rise much more rapidly than the prices of goods. This is the cost disease process.

Baumol provides an extreme example from the entertainment industry that is often repeated in discussions of cost disease. He notes that "a half hour horn quintet calls for the expenditure of 2.5 man hours, and any attempt to increase productivity here is likely to be viewed with concern by critics and audiences alike." (1967, p. 416). On the other hand, productivity gains are indeed possible in higher education. Technological innovations like closed circuit television in the 1960s or web-based distance learning today have the potential to increase productivity. Yet, at least to this point, the primary delivery vehicle remains the faculty member who interacts with students. An institution can increase class size to raise measured output (students taught per faculty year) or use less expensive adjunct teachers to deliver the service, but these examples of productivity gain are likely to be perceived as decreases in quality. An institution can also increase the number of courses each faculty member teaches per year, but not without having an impact on other attributes of output such as research or public service.

At roughly the same time Baumol was developing his cost disease theory international economists were grappling with a related phenomenon. One of the oldest stylized facts in economics is that the cost of living is systematically higher, and the value of money is correspondingly lower, in countries with higher average standards of living. In other words, $\$ 1,000$ buys more in Djakarta than in Detroit. The Penn World Tables calculates national price level information from disaggregated microeconomic data. ${ }^{6}$ In Figure 2, the most recent base year data from 2000 show the clear relationship between

\footnotetext{
${ }^{6}$ These data are available from the Center for International Comparisons at the University of Pennsylvania (http://pwt.econ.upenn.edu/).
} 
level of development and national price level for a fixed basket of goods and services.

\section{Figure 2. Comparing National Price Levels}

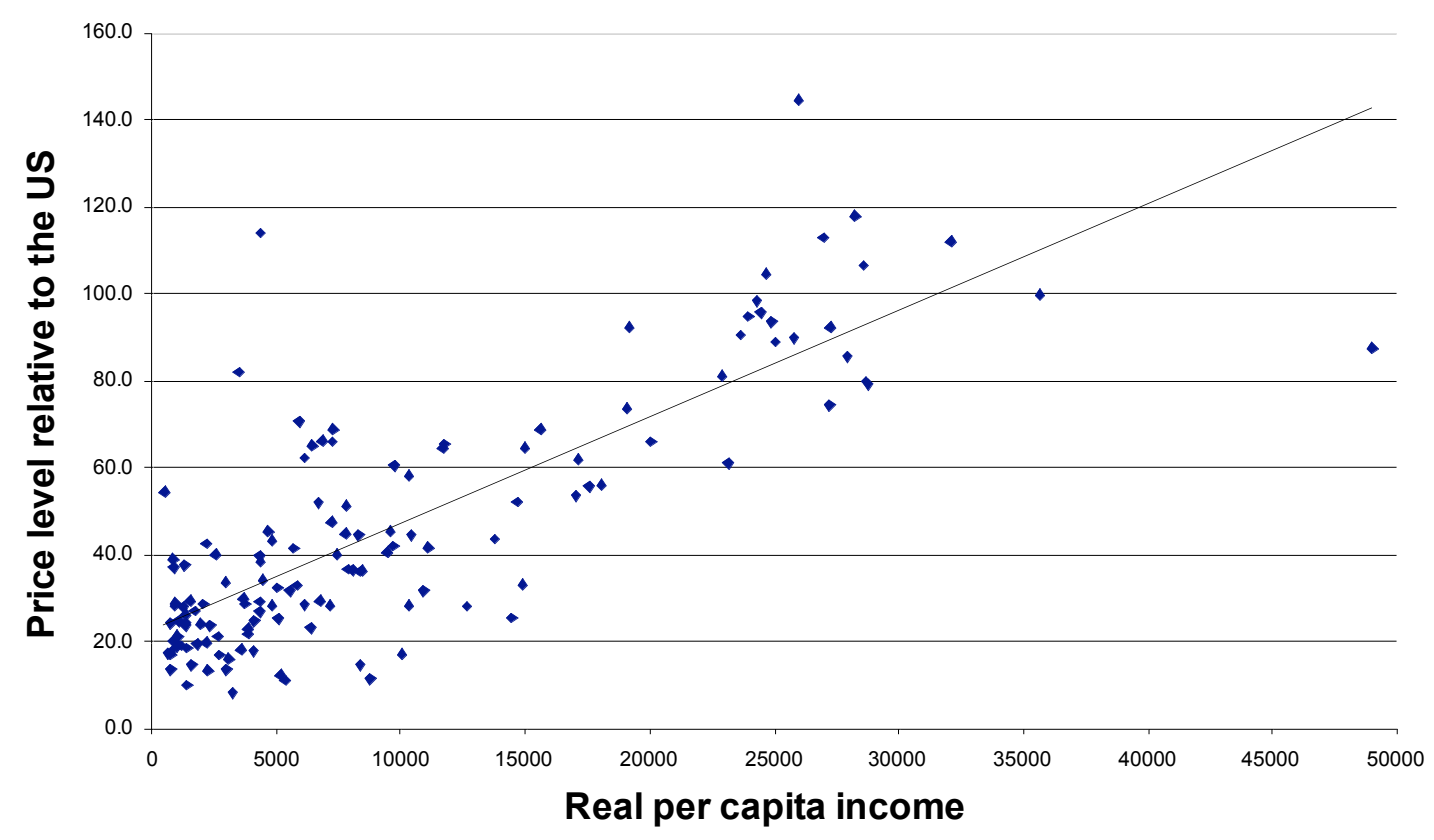

As long ago as 1817, David Ricardo noted this phenomenon and identified the probable cause. Ricardo claimed that "The prices of home commodities ... are higher in those countries where manufactures flourish." [Ricardo (1821) Ch. 7, paragraph 35]. The term "home commodities" is Ricardo's language for non-tradable goods and services. Goods may be non-tradable because of large transport costs relative to value. Services often are non-tradable because of their mode of delivery - you have to go to the provider. Ricardo asserted almost two hundred years ago that the price level would be higher in countries that were further up the development ladder, and the reason would be that richer nations' non-tradable goods and services would cost more locally than would the corresponding goods and services in poorer nations' domestic markets.

This claim is the international cross-section counterpart to cost disease. In 1964 Bela Balassa and Paul Samuelson simultaneously advanced the proposition that the 
positive correlation between the price level and real per capita income could be explained by productivity differentials between nations. The average level of labor productivity is higher in richer nations than in poorer nations. This is why the richer nations are richer. But they argue that the productivity advantage is concentrated in tradable goods, not in non-tradable services. In the absence of significant trade barriers, international trade tends to equalize the prices of tradable goods across countries. This means that wage rates will be higher in countries that have higher labor productivity in these tradable goods. Higher wages also push up service prices in richer countries because there is no service sector productivity advantage in richer countries to match their advantage in tradable goods. In plain language, a half hour hair cut or hour-long university lecture should cost less in a poorer country but a Toyota or a barrel of oil would not. Since the overall price level is a weighted average of prices for tradable goods and non-tradable services, the price level should be higher in richer nations. This became the BalassaSamuelson hypothesis, which is one of the most well-established propositions in international economics. Clearly, if the cost disease phenomenon were present in each nation, then as countries become richer (through productivity growth in manufacturing) their service prices indeed would tend to rise.

Revenue Theory of Cost - Howard Bowen summarizes his theory this way:

On the whole, unit cost is determined neither by rigid technological requirements of delivering educational services nor by some abstract standard of need. It is determined rather by the revenue available for education that can be raised per student unit. Technology and need affect unit costs only as they influence those who control revenues and enrollments. (p. 18)

It is easy to see why this argument was named the revenue theory of cost. Using Figure 1, universities see the quality/cost locus as a constraint. They work assiduously to loosen 
the revenue constraint since that is the path to higher quality. Since universities spend all they are given, the gain in quality from the last dollar of spending may be positive but low in comparison to the social value of the same public dollar spent somewhere else, like health care or K-12 education. In Bowen's view, public restraint is a guarantor that keeps universities from wasteful overspending.

There are two ways to interpret the revenue theory of cost. First, it might be trivial. In a non-profit setting, cost equal revenues, so in each period the revenues available determine the costs that can be expended. This is not very illuminating. Bowen had something more in mind. By claiming that the determination of unit cost is separable from "rigid" technology or "abstract standard of need" he puts revenue in control and ignores or downplays other factors.

Because revenue is the constraint on costs, Bowen expects colleges and universities to do everything they can to loosen the constraint. His third "law" of higher education costs states "Each institution raises all the money it can." (p. 20), yet a look at tuition setting behavior shows that universities are not revenue maximizers. The fact that selective universities commonly draw students from their waiting lists is evidence that excess demand exists for places at those schools. ${ }^{7}$ Universities with excess demand could increase charges without suffering any excess capacity. One could argue that raising price might decrease the yield of high quality students, and that this would harm the overall quality of the institution. Indeed this is true. Many institutions practice need blind admissions in order to attract the best possible student body. These institutions clearly leave revenue on the table. This behavior suggests that Colleges and universities maximize some measure of excellence, prestige, or quality, but not revenue. This is

\footnotetext{
${ }^{7}$ David Breneman (2001) makes the same point (see page 17).
} 
Bowen's first "law" - "The dominant goal of institutions are educational excellence, prestige, and influence." (p. 19). The difficulty is clear, there are conflicts among Bowen's "laws." The institution can maximize quality, or it can maximize revenue. It cannot do both. And at least in setting tuition, the maximization of quality trumps the maximization of revenue.

We can attempt to resolve the conflict in Bowen's "laws" without losing the spirit of his argument. He is saying that institutions maximize "educational excellence, prestige and influence" facing a revenue constraint, and they do what they can to loosen that constraint without doing damage to their main objective. The instances in which institutions fail to maximize revenue are simply times in which doing so would do damage to the quality of the education they could offer. Also, it is worth noting that tuition revenue is probably the only type of revenue that institutions are not interested in maximizing. Larger donations and larger state appropriations are always preferred to smaller ones.

Given Bowen's argument, the difficulty policy makers really have with colleges and universities concerns aspirations of quality. Colleges and universities want everincreasing quality, but policy makers are not convinced that these quality gains are worth the associated expense. The only way that Bowen sees to control the institutions is to control their revenue. On the other hand, if cost disease is real then public institutions are condemned to perpetual decline relative to private colleges and universities so long as private donors think differently about quality than do state legislatures. ${ }^{8}$

The Two Theories and the Time Series Data - Bowen and other authors who put forward higher education-specific explanations for increases in higher education costs

\footnotetext{
${ }^{8}$ See Kane, Orszag and Gunter (2003).
} 
were quite familiar with the cost disease explanation. On occasion these analysts went to some lengths to explain why they did not endorse it. Two of these discussions deserve some scrutiny.

Massy (2003) gives two reasons for why he discounts cost disease both as an explanation of the past and as a forecast of the future. First he claims that Baumol-style cost push can account for only a small fraction of the current increases in higher education cost. His argument is problematic for a number of reasons. He assumes that non-faculty labor costs, which comprise ten to twenty percent of educational and general expense, are not rising at rates similar to faculty salaries. This is very unlikely since a large number of administrators, laboratory technicians, librarians, health and counseling staff, and information technology support personnel are very highly educated. He assumes also that the rest of an institution's costs are subject to normal productivity gains, which is a heroic assumption since many non-faculty activities provided by colleges and universities are themselves services. Massy also emphasizes the possibility of future productivity growth within higher education. This is indeed the only way to break the grip of cost disease and there is some scope for productivity change in all economic activities, but the possibility of productivity growth in the future is no reason to dismiss the importance of the lack of productivity growth in the past.

Bowen's rejection of cost disease is rooted in the time series behavior of real cost per full time equivalent student. His basic claim is that the cost disease explanation is inconsistent with the broad pattern of data on higher education costs. Figure 3 presents the time series data for Real Educational and General Expenditures (E\&G) per student for 
$1929-1995 .^{9}$ These data cover all higher education institutions, public and private, including two-year and four-year institutions. Bowen relies on these time series observations as the basis for his claim that the cost disease explanation is unsatisfactory.

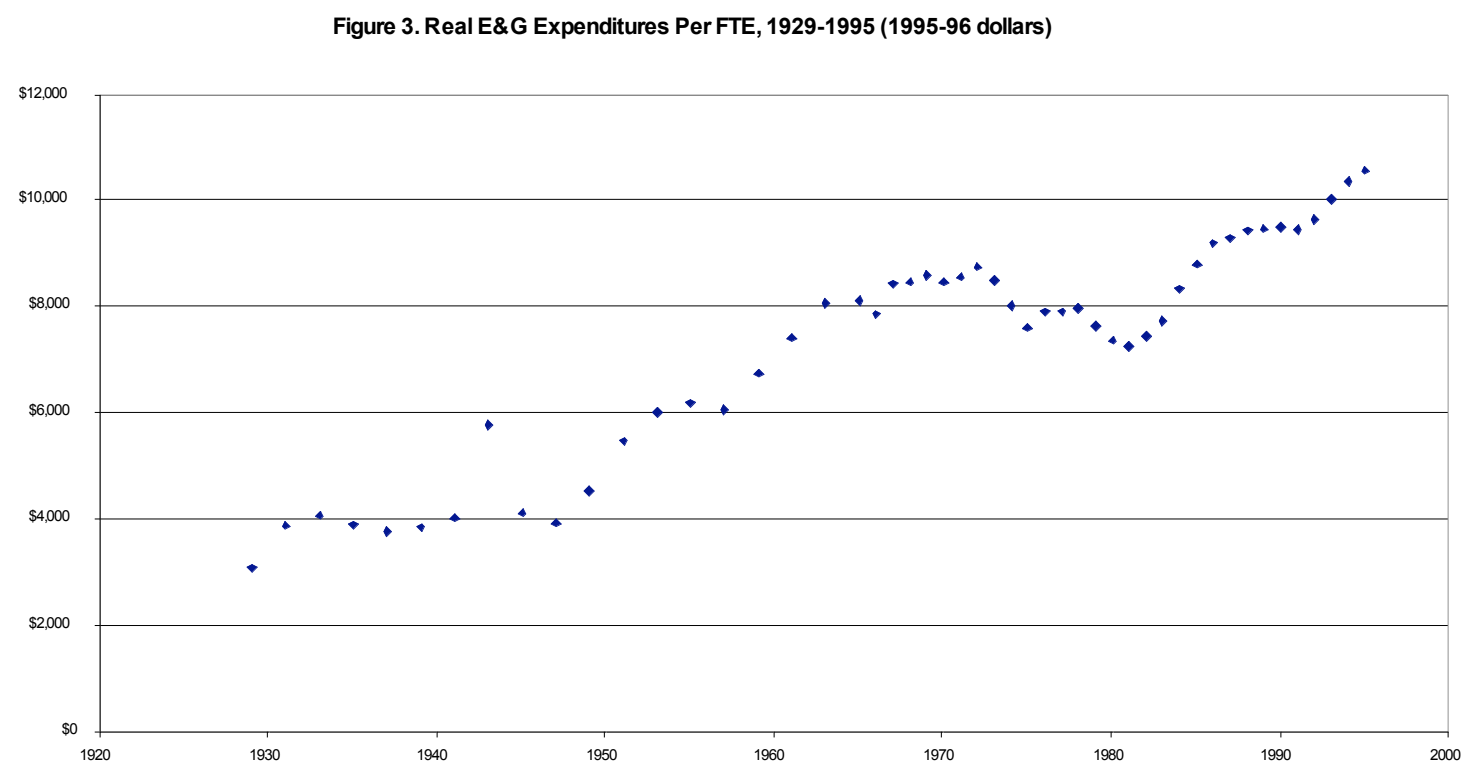

There is one obvious anomaly in the data. It occurs in 1943, which is out of line with the surrounding data points (the early data are biannual). This anomaly is caused by a precipitous drop in enrollment, no doubt caused by the war, accompanied by much less severe drops in expenditures. Otherwise the year to year changes in the data are fairly consistent. They show level real E\&G spending per student in the 1930s and 1940s. This period was followed by a sustained rise from roughly 1950 to 1970 . Thereafter real expenditures per student stopped increasing and fell slightly until the early 1980s. Real expenditures resumed their upward march in the early 1980s at a rate that is as rapid as the rate observed in the 1950s and 1960s.

\footnotetext{
${ }^{9}$ The data can be found in the Digest of Educational Statistics, 2000, Table 339. Data on expenditures in higher education after the 1995-96 academic year are not comparable.
} 
The potential for difficulties with the cost disease explanation are concentrated in the 1929 to 1982 period. During that period the entire cost rise was concentrated in a burst of activity between 1950 and 1970. In constant dollars, educational expenditures per full time equivalent student remained roughly constant between 1931-32 and 194950. Using Bowen's adjustments for changes to the composition of the student population (the increasing proportion of more expensive graduate students), real expenditures per FTE student in higher education actually decreased. Real expenditures then doubled over the period $1949-50$ to $1969-70 .^{10}$. Between 1970 and 1982, real cost per FTE student again declined. ${ }^{11}$ These periods of the declining real costs for higher education are what caused Bowen to dismiss and Thomas Kane (1999) to question the importance of the cost disease explanation.

In the aftermath of the Second World War public funds began flowing into higher education. This period saw the expansion of the role of government that persists to this day. Public higher education expanded dramatically, and cost per FTE student rose.

Rising real appropriations came to an end with what we now call the tax revolt. ${ }^{12}$ At least for public institutions the rate of cost increase in this time period is thus seemingly a function of the revenues made available through the political process. This is Bowen's interpretation. $^{13}$ Our review of the time series evidence is quite different. The existence

\footnotetext{
${ }^{10}$ These data are in Bowen (1980). There were taken from the Digest of Education Statistics (1978, pp. 134-35). Public and private institutions are aggregated together, and because of changes in accounting standards the data cannot be linked with the more recent disaggregated IPEDS data.

${ }^{11}$ Kane's data also come from the Digest of Education Statistics (1997, table 334, p. 350). The data are essentially equivalent to those in Bowen and those in Figure 2.

${ }^{12}$ Archibald and Feldman (2006) describe the role of two primary tax revolt institutions (Tax and Expenditure Limits and supermajority requirements to pass tax increases) in shaping the timing and magnitude of changes in state higher education spending.

${ }^{13}$ See Bowen (1980) page 37-47.
} 
of these periods during which real spending per student declined does not necessarily mean that the cost disease explanation fails for higher education. ${ }^{14}$

First, the decade starting in 1972 was a period of slow productivity growth. Bureau of Labor Statistics data for output per hour in manufacturing show that productivity grew $3.04 \%$ from $1960-1972,1.81 \%$ from $1973-1981$, and $3.16 \%$ from 1982-1995. The cost disease explanation relies on rising productivity as the engine for rising real wages which generates rising costs in service industries. Absent rapid growth in real wages, there will not be rapid growth in costs in an industry like higher education. On the basis of the productivity data alone, we would expect less rapid increases in higher education costs during the 1973-1982 period.

Second, there were important changes in the relationship between wages and education. Between 1970 and the early 1980s the average earnings of male workers with five or more years of college education fell approximately twenty percent in real terms. Faculty salaries tracked downward with them. ${ }^{15}$ Between 1970 and 1982 faculty salaries at public four-year institutions had fallen almost twenty-five percent in real terms. The fall at private universities was slightly greater at thirty percent. The returns to education rebounded in the 1980s, and they are an important part of the reason why college costs started to increase in real terms. These reductions in the returns to higher education, and the associated decreases in faculty salaries have roots in the changing structure of the overall economy, and they clearly affected costs in higher education. Combined with the decline in productivity growth, the reductions in the real salaries of important workers in

\footnotetext{
${ }^{14}$ In what follows we focus on the decline in expenditures in the 1970s and ignore the similar period in the 1930s and 1940s. The peculiarities of the Great Depression in the 1930s and World War II in the 1940s make it hard to make generalizations based on data in these decades.

${ }^{15}$ See Kane (1999) p. 75 for a discussion of the decreases in faculty salaries during this time period.
} 
higher education are consistent with a considerable slowing of the growth in real prices in higher education.

Third, the data for higher education in Figure 3 cover both two-year and four-year institutions, and the second period of decline in the real costs in higher education was a period of very rapid expansion in two-year institutions. Costs per student at two-year institutions are significantly lower than costs per student at four-year institutions. If the data on real cost per FTE student had been calculated using a constant mix of institution types, cost would have grown one percent more rapidly and the measured cost per FTE from the early 1970 s to the early 1980 s would have shown a much less significant decline. ${ }^{16}$ In summary, there are several arguments that a proponent of the cost disease explanation for higher education costs can use to explain the declining real costs in higher education in the 1970s in Figure 3.

In addition, a focus on the periods of decline of Figure 3 is not the only way one can approach the data. It is possible to view the entire sweep of the historical evidence by breaking the data since 1929 into two distinct periods, using 1981 as a break. From 1929 to 1981 real cost per FTE equivalent student grew at an annual rate of $1.66 \%$. From 1981 through 1995 the rate of cost increase accelerated to $2.74 \%$. This acceleration in real cost after the early 1980 s has occurred despite the restraint in state appropriations to public colleges and universities.

Perhaps the single most salient structural explanation for this break in the 1980s is the evolving economic return to higher education. The period of slower cost increase was dominated by what Claudia Goldin and Robert Margo (1992) have called "The Great Compression." In 1940, an American male at the $90^{\text {th }}$ percentile of the income

\footnotetext{
${ }^{16}$ The detailed calculation is available from the authors on request.
} 
distribution earned five times as much as a man at the $10^{\text {th }}$ percentile. By 1950 the gap had shrunk to a factor of three. In terms of years of schooling, between 1940 and 1950 there was a thirteen percent decrease in the wage premium for college graduates. Goldin and Margo estimate that almost half of the compression was due to falling returns to schooling. The Great Compression also had staying power. Male wage differentials in 1975 were very similar to their 1945 levels. This extraordinary smoothing of the income distribution went into reverse starting in the late 1970s. By 1999 the 90-10 gap for male workers had risen to 5.4. Again, much of this increased income dispersion results from a rising earnings gap between college graduates and those with a high school degree or less. ${ }^{17}$

Highly trained labor is an integral component of producing higher education. Wages and benefits comprise seventy to eighty percent of a university's operating budget. Most of that labor expense results from the industry's intensive use of highly educated labor. Faculty and administrators are the most obvious source of cost, but much of the support staff at a university also has a university degree or more. This includes everything from librarians and IT personnel to departmental executive secretaries.

Summary - Our objective in the foregoing discussion was not to make an argument for one or the other of the explanations for the rise in higher education costs, but rather to indicate that it is very difficult to use the time series evidence to sort out which of the two theories provides the more satisfactory explanation. The periods during which real higher education costs declined clearly cast some doubt on an explanation that seems to point to continually increasing real costs, yet there are other factors that make

\footnotetext{
${ }^{17}$ Thomas Lemieux (2006) presents evidence indicating that the rise in the 90-10 gap is accentuated for more highly educated workers.
} 
these periods of decline plausible in the context of the cost disease explanation. The time series evidence in Figure 3 is not sufficient to allow one to distinguish between the two explanations.

\section{A Test of the Competing Theories}

To separate these two explanations we have to turn to cross section data. The data come from the prices indexes for Personal Consumption Expenditure by Type of Product generated by the Bureau of Economic Analysis of the Department of Commerce. ${ }^{18}$ These data come from the Gross Domestic Product accounts, which record expenditures and prices for the final purchaser of the good or service. As a result the classification of some product categories may seem strange. For example, the product category Gas is classified as a service because the final purchaser is paying for the service of having natural gas delivered to his or her home. There are several service categories that have the characteristic that a large portion of the price of the service is bound up in the price of the product being delivered.

Using the lowest level of aggregation with continuous data from 1929, there are price indexes for sixty-nine individual product categories, thirteen of which are durable goods, seventeen of which are nondurable goods and thirty-nine of which are services. ${ }^{19}$ We can compute the rate of increase of prices for all sixty-nine of these product categories. We will be comparing the behavior of these prices with the behavior of cost per full-time equivalent student because there is no time series evidence for costs in these industries. In higher education, subsidies allow colleges and universities to set prices

\footnotetext{
${ }^{18}$ They can be found in Table 2.4.4 on the BEA website.

${ }^{19} \mathrm{We}$ had to eliminate the product category Computers, peripherals, and software because it did not start in 1929.
} 
below costs. Most other firms are not provided subsidies, so prices exceed costs because the unsubsidized industry has to return a profit to its owners. Our maintained assumption will therefore be that there are not systematic changes in the profitability in the industries producing the goods and services that mask the underlying time series behavior of costs. This allows us to compare costs in higher education with prices in other industries.

We are not able to directly test the revenue theory of costs. As we noted earlier, Bowen did not properly specify an objective function that guides university behavior and this renders his theory difficult to frame as a testable hypothesis. Yet one characteristic it shares with several other explanations of costs in higher education is that it is a higher education-specific theory. It relies on factors affecting the revenues in higher education to explain the behavior of cost in higher education. If higher education-specific factors are the primary driver of college and university costs, it would be merely a coincidence if the prices of any of the other product categories in the data had a time pattern similar to the time pattern of costs in higher education. The revenue theory is silent about the products whose price behavior should be similar to higher education costs. On the other hand, the explanation of higher education cost increases based on cost disease makes a prediction. It predicts that costs in higher education will have a time path that is very similar to the time path of the prices of product categories for personal services, particularly personal services which depend upon highly educated labor. This difference in the prediction gives us a chance to sort out which of the theories is more consistent with the data.

There are two ways to think about similar time paths. First, one could simply look the rate of change over a representative time period. The goods with similar time 
paths to higher education would be the goods whose increase in real prices was similar to the increase in real cost per student in higher education. Second, one could compare the shape of the time path of prices for goods and see how close it is to the time path of costs of higher education. The major difference in the two approaches is that the first only uses data from the end points of the time series being compared while the second uses the information in the intervening years.

To construct the measure of how "close" two time series are, we divided the time period from 1949-50 to 1995-96 into eleven four-year long time segments, e.g., 1949-50 to $1953-54,1953-54$ to $1957-58$, etc. ${ }^{20}$ For each of our time segments, we computed a measure of real price in the second year relative to the real price in first year, e.g., we divided the real price of a product category in 1953-54 (to more closely match academic years we averaged of the two years price indexes) by the real price of that product category in 1949-50. We computed cost indexes for higher education in the same manner. We then computed the absolute difference between the price index of each product category and the cost index for higher education over the four year period. If the rate of change of prices for a particular product over a four year period was identical to the rate of change of higher education costs per student, the two measures would be identical and the absolute difference would be zero. The absolute differences would grow as the rates of change in the two series differed. To compute our final measure of the closeness of the two series we averaged the absolute differences over the eleven 4year time segments covering 1949-50 to 1993-94.

\footnotetext{
${ }^{20} \mathrm{We}$ recognize the choices of 4 year time segments and starting in 1949 are arbitrary. We did robustness checks using 10 year, 6 year, and 2 year time segments and series that started in 1929. The results from these exercises were not qualitatively different from the results we report below.
} 
Table 1 presents the results of these calculations with the product categories listed in increasing order of the mean absolute deviation. In this way the product categories whose time series price behavior was most similar to the time series behavior of costs in higher education are at the top of the table. To make them stand out, we have listed the service industries in boldface type and the aggregate measure in ALL CAPS. The third column of the table gives the other comparison, a measure of the real price change over the entire time period. For example, the 1.9185 in the first row of the third column tells us that the product category "Expense of handling life insurance and pension plans" rose 91.85 percent in real terms over this time period.

Table 1. Mean Absolute Deviations Between Prices and Higher Education Costs, 4-year changes, 1949-94 and Real Price Change 1949-50 to 1995-96

$\begin{array}{lrr} & \begin{array}{c}\text { Mean } \\ \text { Absolute }\end{array} & \begin{array}{l}\text { Real Price } \\ \text { change 1949- }\end{array} \\ \text { Product Categories } & \begin{array}{r}\text { Deviation } \\ 50 \text { to 1995-96 }\end{array} \\ \text { Expense of handling life insurance and pension plans } & 0.7685 & 1.9185 \\ \text { Higher education } & 0.9032 & 2.0133 \\ \text { Funeral and burial expenses } & 0.9268 & 1.7441 \\ \text { Other user-operated transportation } & 0.9295 & 1.7793 \\ \text { Tobacco products } & 0.9365 & 1.8321 \\ \text { Dentists } & 0.9376 & 1.9106 \\ \text { Services furnished without payment by financial intermediaries except } & & \\ \text { life insurance carriers } & 0.9758 & 1.9333 \\ \text { Hospitals and nursing homes } & 1.0048 & 2.5147 \\ \text { Admissions to specified spectator amusements } & 1.0264 & 1.4511 \\ \text { Legal services } & 1.0306 & 3.4640 \\ \text { Water and other sanitary services } & 1.0343 & 2.8193 \\ \text { Other Household Services } & 1.0439 & 1.5745 \\ \text { Mass transit systems } & 1.0644 & 2.2654 \\ \text { Tenant-occupied nonfarm dwellings--rent } & 1.0843 & 1.0772 \\ \text { Magazines, newspapers, and sheet music } & 1.0854 & 1.5790 \\ \text { Owner-occupied nonfarm dwellings--space rent } & 1.0915 & 1.0858 \\ \text { Other professional services } & 1.1125 & 1.9187 \\ \text { Other Housing } & 1.1161 & 1.6675 \\ \text { Physicians } & 1.1262 & 2.5281 \\ \text { Other Recreation } & 1.1366 & 1.0323 \\ \text { Other Personal Business } & 1.1581 & 1.4054 \\ \text { Health insurance } & 1.1630 & 1.9272 \\ \text { Taxicab } & 1.1642 & 1.6465 \\ \text { PERSONAL CONSUMPTION EXPENDITURES } & 1.1819 & 1.0000\end{array}$


Other Personal Care Services

Purchased meals and beverages

Ophthalmic products and orthopedic appliances

1.2094

0.8913

Cleaning, storage, and repair of clothing and shoes

1.2194

1.3626

Domestic service

Repair, greasing, washing, parking, storage, rental, and leasing

Barbershops, beauty parlors, and health clubs

Drug preparations and sundries

1.3194

0.8104

Religious and welfare activities

1.3210

1.1950

Rental value of farm dwellings

1.3400

1.0256

Stationery and writing supplies

1.3651

1.0579

Books and maps

1.3681

1.4155

Nursery, elementary, and secondary schools

1.3750

1.7181

Bus

1.3817

1.5884

Food purchased for off-premise consumption

1.4306

0.8674

Other Education and Research

1.4471

1.2159

Other motor vehicles

1.4585

0.7485

\section{Other Purchased Transportation}

China, glassware, tableware, and utensils

1.4654

1.4887

1.2592

Furniture, including mattresses and bedsprings

Food furnished to employees (including military) and food produced and

1.5070

0.9847

consumed on farms

1.5105

0.6096

Shoes

Toilet articles and preparations

Flowers, seeds, and potted plants

Bank service charges, trust services, and safe deposit box rental

New autos

Railway

Other durable house furnishings

Men's and boys' clothing and accessories except shoes

Semidurable house furnishings

Wheel goods, sports and photographic equipment, boats, and pleasure aircraft

1.5208

0.8881

1.5272

0.6572

1.5288

0.7425

1.5919

0.6010

1.6046

1.7780

0.5987

1.6096

1.3221

1.6480

0.5150

1.6797

0.4795

1.6930

0.5047

Cleaning and polishing preparations, and miscellaneous household supplies and paper products

1.7156

0.4847

Airline

Jewelry and watches

Nondurable toys and sport supplies

Telephone and telegraph

Electricity

Tires, tubes, accessories, and other parts

Women's and children's clothing and accessories except shoes

Brokerage charges and investment counseling

Gas

1.7481

0.9006

1.7534

0.7998

1.7806

0.4663

1.7829

0.4370

1.8148

0.4183

1.8254

0.8612

1.8998

0.4260

1.9155

0.3520

2.1010

2.2600

2.1974

1.4189

Kitchen and other household appliances

2.2855

0.2638

Gasoline and oil

2.3432

0.9359

Fuel oil and coal

3.0344

1.4576

Video and audio goods, including musical instruments

3.0404

0.0979

Net purchases of used autos

3.9376

3.1633 
An inspection of the table indicates that the product categories at the top of the table, those whose pricing behavior is most similar to the behavior of costs per student in higher education, are not a random selection from the product categories. There are sixty-nine product categories, thirteen of which are durable goods, seventeen of which are nondurable goods, and thirty-nine of which are services. The top twenty product categories in the table contain eighteen services and two goods (Magazines, newspapers and sheet music, and Tobacco products). The probability of twenty random draws yielding eighteen, nineteen, or twenty services from a population which contains thirtynine services and thirty goods is $.0003 .^{21}$ This result is sufficient for us to reject the hypothesis that the product categories whose pricing behavior most resembles costs in higher education are randomly drawn from services and goods.

The statistical test simply used the distinction between goods and services. The cost disease explanation is based on characteristics of personal services, not simply services. For higher education the hypothesis should be that costs rise in a similar fashion as the prices of personal service industries which utilize highly educated labor. Because there is no clear cut way to define the exact set of product categories with the desired characteristics, we cannot offer a statistical test. Inspection of the table, however, is sufficient to demonstrate the plausibility of the prediction. The top of the table includes several product categories that should be dominated by the types of service providers in question: Expenses of handling life insurance and pension plans (statisticians and actuaries), Dentists, Physicians, Other professional services (not dentists or physicians, so chiropractors and optometrists etc.), and Legal services. In general the

\footnotetext{
${ }^{21}$ This probability is calculated using the Hypergeometric Distribution, which is appropriate in cases such as this in which sampling is without replacement.
} 
services which are further down the list are either personal services which utilize less well educated labor, e.g. Barbershops, beauty parlors, and health clubs, Other personal care services, and Domestic services, or they are not personal services, e.g. Railway, Telephone and telegraph, Bus, Airline, Electricity, and Gas.

The exception to these generalizations is the product category Brokerage charges and investment counseling, which is a personal service that is typically provided by highly educated professionals. Pricing behavior in this product category is clearly out of line with the pricing behavior of the other personal services provided by highly educated labor and with costs in higher education. It is easy to see why brokerage services are different. This is an industry which has experienced dramatic productivity gains associated with online trading of stock and bonds -- to make a trade one no longer has to meet a broker face to face, or even over the phone -- and the process of completing the trade involves many more computers and fewer face to face exchanges. ${ }^{22}$ The cost disease story relies on lagging productivity growth; at least in the computer age, Brokerage charges and investment counseling does not satisfy this condition.

The third column of the table gives the real price change from 1949-50 to 199596. The comparable number for real cost per full-time equivalent student in higher education is 2.7149 , which is higher than all but three of the product categories in the table (Legal services, Net purchase of used autos, and Water and other sanitary services) ${ }^{23}$ The prices of the product categories in the top of the table, those more

\footnotetext{
${ }^{22}$ The data on productivity in the service sector in Jack E. Triplett and Barry P. Bosworth (2004) show that the industry Security and commodity brokers has the most rapid rate of productivity of any of the industries studied over the 1987-2001 period. (See page 18-19).

${ }^{23}$ The product category Higher Education is a price index based on the list price of higher education and should not be confused with the data for higher education costs. The fact that Higher Education prices move very similarly to higher education costs should not be surprising. The fact that the overall increase in higher education costs is greater than the overall increase in prices in higher education prices indicates that
} 
similar to higher education, clearly rose much rapidly than the prices of the product categories further down the table. The average for the top twenty product categories is 1.9054 while the average for the bottom 20 product categories is .9082 . Clearly there are anomalies. Again, Brokerage charges and investment counseling is unusual. It is near the bottom of the table, but its prices increased considerably.

Figure 4 helps us understand the information in the table. In this figure we have graphed the real price information for selected product categories and for higher education costs for 1949-50, 1969-70, 1979-80, 1989-90, and 1995-96. We used 1949-50 as the base so each series starts at 1.00 in 1949-50. The 1995-96 entries, at the right-hand edge of the figure, are the values in the third column in the table.

There are several results illustrated by this figure. First, the prices of the three goods (Food for off premises consumption, Shoes, and New Autos) all decreases in real terms, so their time series behavior was not very similar to costs in higher education or the services represented. Second, the reason that the final price increase of Brokerage charges and investment counseling is close to the change higher education costs but the the rising importance of public higher education since 1949. 
Figure 4. Timepath of Real Product Category Prices, 1929-95

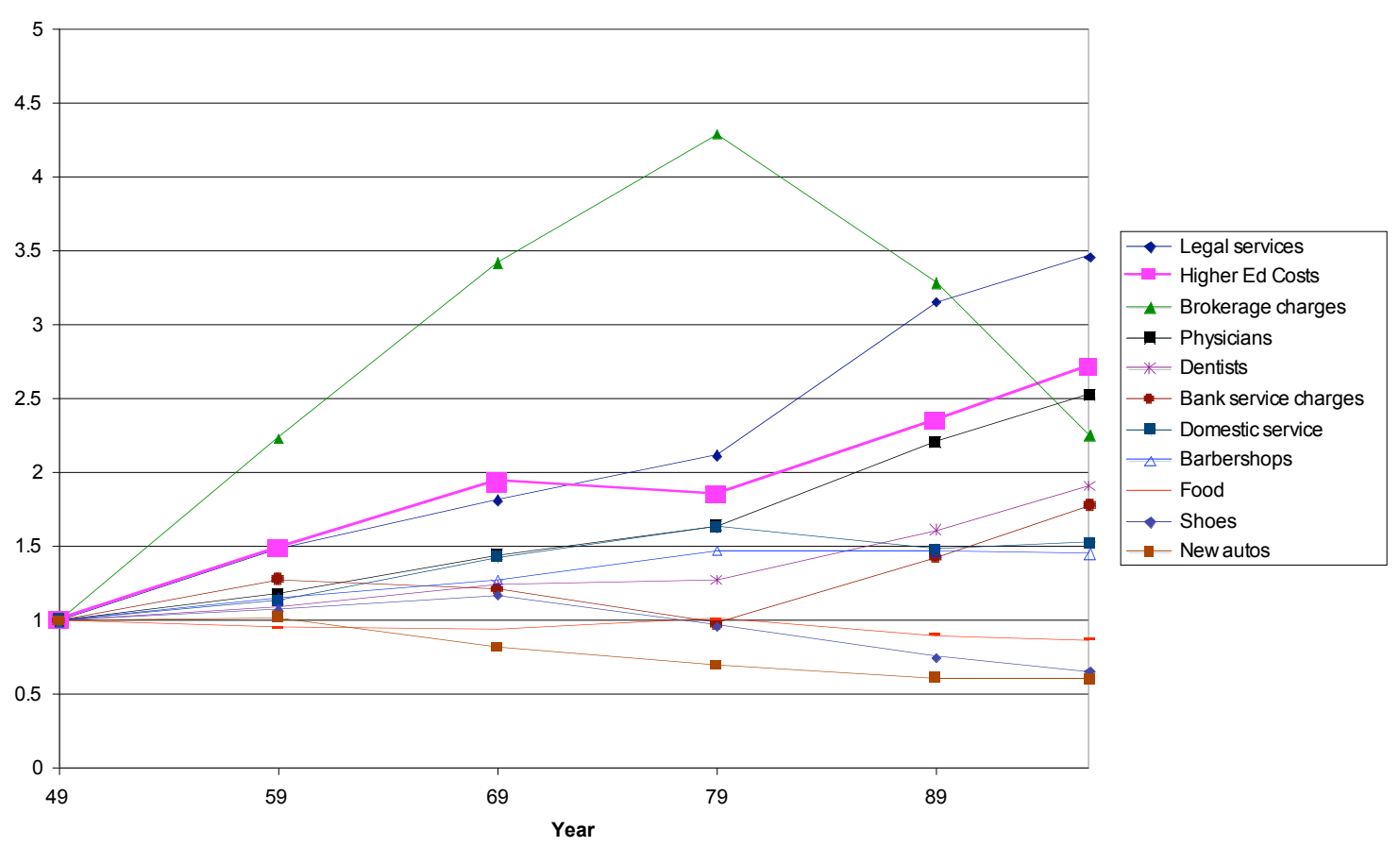

time series behavior of the two series is dissimilar is clear. Brokerage charges rose dramatically and then fell after 1979-80, which is very different from the time path of higher education costs, which started to rise more rapidly after 1979-80. Third, the time paths of prices of the services utilizing highly educated labor, which includes legal services, physicians, and dentists, and the time path of the costs of higher education all increase in slope after 1979-80. In contrast, the time paths of the prices of services utilizing less highly educated labor, such as Domestic service and Barbershops, beauty shops and health clubs, leveled off after 1979-80. This evidence is consistent with the importance of the increase in the returns to education starting in the $1980 \mathrm{~s}$.

This evidence persuades us that higher education-specific explanations are not the best way to think about higher education costs. In fact, there is good evidence that country specific explanations are similarly deficient. As Baumol and Blackman (1995) 
note, the long term growth rate of the real cost of higher education in the United States is quite average compared to other nations. The most striking comparison is between the US and Japan. Baumol and Blackman use UNESCO data to calculate the growth rate of the real price of higher education between 1965 and 1988, which is the period when Japanese labor productivity in manufacturing was soaring relative to the US. During these years, the average annual growth rate of labor productivity in manufacturing was 2.8 percent in the US and 6.2 percent in Japan. The cost of higher education rose at an annual rate of 5.56 percent in Japan but only 2.91 percent per year in the US.

Conclusion - One can approach the study of costs in higher education, or in any other industry, by focusing on the things that make the industry different from other industries or on the things that make it similar to other industries. Clearly the best explanation should account for both the differences and the similarities. The empirical question is which is most important. Without clear evidence, one should be suspicious of arguments like the revenue theory of costs that focus solely on specific features of an industry. Our analysis should turn this suspicion into disbelief. Cost per student in higher education follows a time path very similar to the time path of other personal service industries that rely on highly educated labor. This is entirely consistent with the cost disease explanation of the rise in cost in higher education. This explanation is based on strong economy-wide influences that affect industries that tend to experience lagging productivity growth and rely on highly educated labor, not on characteristics of higher education itself.

While this evidence should not lead one completely to dismiss higher educationspecific factors as part of the explanation for the rise in college costs, it makes it 
exceedingly difficult to sustain the position that these explanations are the whole story. In our view, the correct way to view past experience is to recognize that higher education behaves much the same way as other personal services industries utilizing highly educated labor. This does not mean that there is no role for higher education specific factors, but it limits their role. Higher education specific factors represent reasons why the cost behavior of higher education might be slightly different from the norm, but only slightly different. The data clearly are telling us that the cost disease phenomenon is the dominant reason that higher education costs have risen in such a sustained manner over the past eighty years.

\section{Policy Consequences}

We have shown that cost disease likely has played the most significant role in driving the cost of higher education per FTE student upward over the past eighty years. Thus the problem over the whole time period has been lagging productivity growth in personal services relative to manufactured commodities. Lagging productivity growth in personal services puts upward pressure on the relative price of these services because wage growth in this sector is not offset by higher labor productivity. More recently, the rising wage premium for highly educated workers has put additional upward pressure on all personal services that rely extensively on educated labor. Higher education is one such sector.

Clearly there are those who understand the need to increase productivity in higher education, and there is an active research agenda that seeks to find ways to use information technology more effectively in higher education. ${ }^{24}$ The National Center for Academic Transformation has sponsored a program in course redesign focusing on

${ }^{24}$ See Carol A. Twigg (2005). 
introductory courses across the curriculum. The potential for quality-preserving (or enhancing) cost decreases from more fully integrating information technology into the delivery of higher education may be the greatest in introductory classes that service large segments of the student population. Referring back to Figure 1, if integrating information technology more fully into the design of service delivery can yield productivity gains then the cost-quality locus shifts downward. Cost decreases could be achieved without reducing quality, or alternatively higher quality is possible at constant costs. The costquality relationship is a menu of possibilities. The stakeholders in higher education will decide where on that locus to operate.

Yet many of the policies that have been advanced recently are a form of price controls that focus instead on punishing institutions whose list price tuition rises "too fast." A good example are the proposals emanating from the House Committee on Education and the Workforce that would link a university's access to federal aid programs to the rate of tuition increase. ${ }^{25}$ Controlling university revenues will not freeze cost pressures in higher education. Policy makers can hold public subsidies constant in real terms, and they can cap tuition increases - i.e. price controls. Doing so will force universities to limit their spending. The larger problem for colleges and universities is that policy makers often behave as though these two control levers are completely independent of the third basic feature of the American higher education system, which is

\footnotetext{
${ }^{25}$ The committee's 2003 report titled "The College Cost Crisis" by John A. Boehner and Howard P. McKeon assigns most of the blame for tuition increases outstripping inflation to wasteful spending priorities at universities, and not to long term trends in state subsidization of public universities or to arguments like Baumol's about structural forces that drive up underlying costs over time. This notion is bipartisan. In the last presidential race, Sen. John Kerry outlined a plan surprisingly similar to what was advanced by House republicans. Instead of a stick, Kerry advocated a funding carrot to induce states to keep tuition increases at their state universities under control. Under his plan, states would have been able to tap new federal grants from a pool of up to $\$ 5$ billion per year for higher education if their tuition increases are in line with inflation.
} 
quality. In fact, within the existing technology for service delivery for service delivery, decisions to manipulate two of these must affect the third. This is the unholy trinity of higher education finance. Increasing public funding allows higher quality programs at a constant tuition. Higher tuition permits better offerings at existing subsidy levels. In the face of upward cost pressures, capping tuition increases while holding per-student public subsidies constant must reduce quality. Thus controlling cost by restricting revenue has side effects that may not be desirable. It is important for policy makers and the public to understand the tradeoffs they face as they think about strategies to control higher education costs.

Increasing the low rate of productivity growth in higher education is not easy. Simple fixes like increasing average class size or using more adjunct teachers certainly can raise output measured as students taught per academic year, but with consequences for perceived quality of the academic program. States have indeed reined in real per student appropriations and state institutions have responded with cost cutting. The primary effect seems to be reduced faculty quality at public institutions and a decline in their quality relative to private universities. The data from the last eighty years are clear; sustained productivity growth in higher education is a trick that has not been accomplished in the past. Yet the scope for productivity change in services is real, as the evidence for Brokerage Services implies and the work of National Center for Academic Transformation is starting to indicate. It is critically important for the long-term health of higher education (especially of public institutions) to find ways to cut costs that preserve the quality of the service we provide. 


\section{Bibliography}

Archibald, Robert B., and Feldman, David H., "State Higher Education Spending and the Tax Revolt," Journal of Higher Education, 77 (July/August 2006), pp. 618-644.

Baumol, William J. Macroeconomics of Unbalanced Growth: The Anatomy of Urban Crisis, The American Economic Review, 57 (June 1967), pp. 415-26.

Baumol, William J., and Blackman, Sue Anne, How to Think About Rising College Costs, Planning for Higher Education, 23 (Summer 1995), pp. 1-7.

Baumol, William J. and William G. Bowen, Performing Arts: The Economic Dilemma, (Twentieth Century Fund, 1966).

Balassa, Bela. The Purchasing-Power Parity Doctrine: A Reappraisal, The Journal of Political Economy, 72 (December 1964), pp. 584-596.

Boehner, John A., and Howard P. McKeon, "The College Cost Crisis." U.S. House Committee on Education and the Workforce and U.S. House Subcommittee on 21st Century Competitiveness, Government Printing Office, 2003.

Bowen, Howard R., The Costs of Higher Education: How Much Do Colleges and Universities Spend per Student and How Much Should They Spend? San Francisco: Jossey-Bass Publishers, 1980.

Breneman, David W. Testimony before the Subcommittee on Postsecondary Education, Training and Lifelong Learning of the House Committee on Economic and Educational Opportunities. Report 104-62. 104 Cong., $2^{\text {nd }}$ sess. Government Printing Office, 1996.

Breneman, David W. "An Essay on College Cost," in Study of College Costs and Prices, 1988-89 to 1997-98, Volume 2: Commissioned Papers, U.S. Department of Education, Office of Educational Research and Improvement, NCES 2002-158, December 2001, pages 13-20.

Ehrenberg, Ronald G., Tuition Rising: Why College Costs So Much, Cambridge, Harvard University Press, 2000.

Getz, Malcolm and John J. Siegfried, Cost and Productivity in American Colleges and Universities, in Charles Clotfelter, Ronald Ehrenberg, Malcolm Getz, and John J. Siegfried (ed), Economic Challenges in Higher Education, Chicago: University of Chicago Press, 1991, pp. 261-392.

Goldin, Claudia and Margo, Robert A. The Great Compression: The Wage Structure in the United States at Mid-Century, Quarterly Journal of Economics, 107 (February 1992), pp. 1-34. 
Kane, Thomas J., The Price of Admission: Rethinking how Americans Pay for College, Washington: The Brookings Institution Press, 1999.

Kane, Thomas J., Orszag, Peter R. and Gunter, David L. "State Fiscal Constraints and Higher Education Spending: The Role of Medicaid and the Business Cycle," Discussion Paper \#11, the Urban-Brookings Tax Policy Center (May 2003).

Lemieux, Thomas, "Postsecondary Education and Increasing Wage Inequality," The American Economic Review, 96 (May 2006), pages 195-199.

Massy, William F., Productivity Issues in Higher Education, ch. 3 of William F. Massy (ed.), Resource Issues in Higher Education, Ann Arbor: University of Michigan Press, 1996.

Massy, William F., Honoring the Trust: Quality and Cost Containment in Higher Education, Bolton: Anker Publishing Company, 2003.

National Commission on the Cost of Higher Education, Straight Talk About College Costs and Prices, Phoenix, The Oryx Press, 1998.

Ricardo, David, "On Foreign Trade," chapter 7 in On the Principles of Political, Economy and Taxation, London: John Murray, 1821.

Samuelson, Paul. Theoretical Notes on Trade Problems, Review of Economics and Statistics, 23 ( May 1964), pp. 145-154.

Triplett, Jack E., and Bosworth, Barry P. Productivity in the U.S. Services Sector: New Sources of Economic Growth, Washington, D.C.: The Brookings Institution, 2004.

Twigg, Carol A. "Improving Quality and Reducing Costs: The Case for Redesign," in College Costs: Making Opportunity Affordable, Lumina Foundation, 2005. 